\title{
Analysis of Performance Appraisal System of the Nigerian Public Sector Organizations
}

\author{
Akpanim Ntekim Ekpe, Ekong E. Daniel, Martha A. Ekpe, \\ Ph.D. (Reader) Faculty of Social and Management Sciences Akwa Ibom State University, Nigeria \\ Ph.D., Faculty of Social and Management Sciences Akwa Ibom State University P. M. B. 1167, Uyo Akwa Ibom \\ State, Nigeria \\ M.Sc., Department of Administration and Planning, University of Calabar, Nigeria
}

\begin{abstract}
One of the human resource management problems which engulfed the public sector organizations in Nigeria was the absence of effective performance appraisal system. Subjective method of staff appraisal hitherto used in the Nigerian public sector emphasized only personal traits such as; drive, honesty, initiative, foresight, loyalty, industry and courage. This method posed human resource management problems, in the areas of promotion, wage increase, selection for training and retraining, job description and placement. As a result, the Nigerian public sector was rendered inefficient and ineffective thus hindering the progress of this important sector of the Nigerian system. However, in 1988 the Civil Service Reform prompted the introduction of target setting and performance appraisal system in the public sector organizations, which was based on "objective assessment, subject to measurable job performance and demonstration of professional competence with effective rewards and sanctions. This paper therefore compared the former performance appraisal system with the present performance appraisal system. It assessed the applicability of the present performance appraisal system to determine its efficiency. Using the concept of strategic human resource management the study observed that the present performance appraisal system will help achieve organizational goals and objectives, meet individual needs and provide competent and well motivated employees in the Nigerian public sectors. It recommends that the reporting officers or scheduled supervisors of public organizations should be specifically trained on how to compute and calculate the new Annual Performance Evaluation Report (APER). This will certainly ease and facilitate hitch free and accurate computation of workers' appraisal.
\end{abstract}

Key words: Civil service, performance appraisal system, strategic human resource management, public sector organizations, Nigeria.

\section{Introduction}

One major human resource management problem which hindered the progress of the public sector in Nigeria was the absence of effective performance appraisal system. The application of the subjective rather than objective performance appraisal system in the public organizations had been posing human resource management in the areas of promotion, wage increase, selection for training and retraining, job description and placement, etc. The subjective method of staff appraisal emphasized personal traits; such as drive, honesty, initiative, foresight, loyalty, industry, courage, penetration, etc, whereas, objective method of staff appraisal stresses enhancement of accountability, improvement in efficiency, effectiveness and speed of operation in the management of public sector organizations. The Udoji Public Service Commission Report (1974) observed that "lack of effective performance appraisal system in organizations was counterproductive, and was repulsive to accountability, efficiency, effectiveness, and speed of operation in the management of public sector organizations in Nigeria". Eventually, the 1988 Civil Service Reform and the Ayida Reform (2008) prompted the introduction of target setting and performance appraisal system in the public sector organizations, which was based on "objective assessment, subject to measurable job performance and demonstration of professional competence with effective rewards and sanctions".

\section{The Study Location}

Nigeria is situated on the Gulf of Guinea in West Africa between latitudes $4^{\circ}$ and $14^{\circ}$ north and longitudes $3^{\circ}$ and $14^{\circ}$ east (see Fig. 1). Its neighbors are Benin, Niger, Cameroon and Chad Republics. There are 36 states in Nigeria, including Abuja, the Federal Capital Territory. The country operates federal system of government. Before its independence on October 1, 1960, the territory now known as The Federal Republic of Nigeria was under the British colonial rule. Today, the country has grown tremendously to a population size of about $152,217,341$ people. Nigeria is an heterogeneous society with multiple cultural, ethnic and lingual diversities. A significant size of the population of the country is employed in the public sector. 


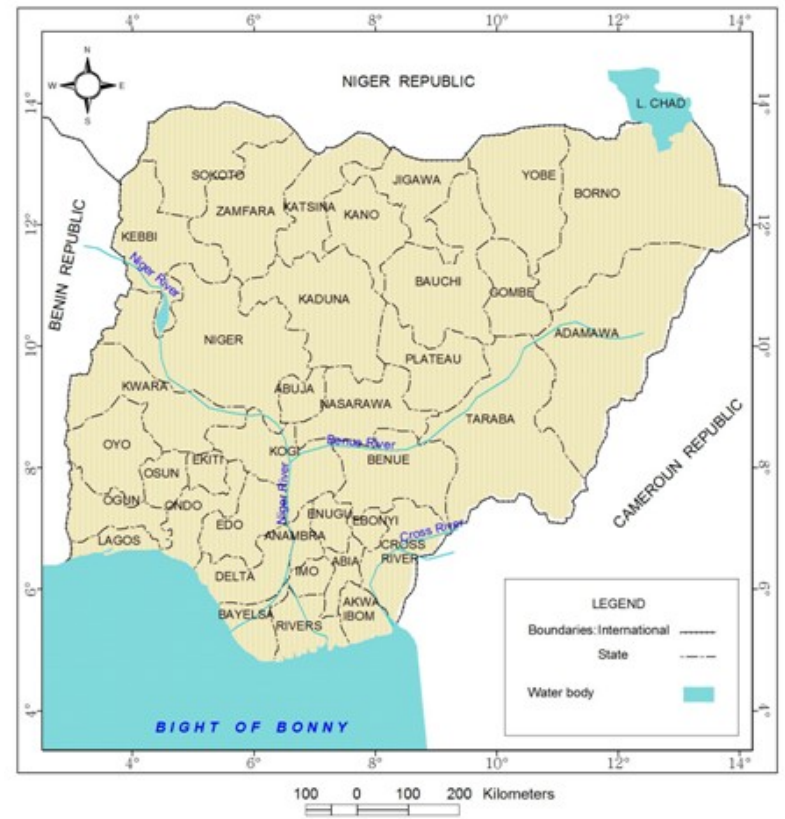

Fig . 1: Nigeria - The Study Location

\section{The Aim and Objectives of the Study}

The aim of the study was to analyze the application and efficiency of the current performance appraisal system in the Nigerian public Sector organizations. To achieve this aim, the following objectives were set out:

1. To highlight the purpose of performance appraisal system in the public sector organizations.

2. To outline the problems associated with the former appraisal system of the Nigeria public sector organizations.

3. To compare the evaluation indices of the two appraisal systems.

4. To practically evaluate the application of the current appraisal system.

\section{Conceptual Framework}

Strategic human resource management: The study was primarily based on strategic human resource management. The term "Strategic Human Resource Management" conveys the sense of human personnel management in a strategic context (Imagha 2001). For this to take place there has to be some connection made with strategic process through which the aims of organization are managed, that connotes strategic management. Pioneer contributors to the literature of strategic management, include among others, Alfred, Chanceller, Phillip Seiznich, Ogor Adolf and Peter Druker (Druker 1990). They all recognized the importance of coordinating the various aspects of management, including Human Resources as encompassing strategy.

The concept of Strategic Human Resource Management is American in origin. As early as 1970's, Human Resource Management as a replacement for traditional personnel management describes a change in the functions, boundaries, and objectives (Miller and Burack 1981). Human resource management emphasizes integrating human resource planning with the strategy of the organization. According to Subba (2000), Human Resource Management (HRM) encompasses those activities derived to provide for and coordinate the human resources of an organization. Human resource functions, therefore, refer to those tasks and duties performed in organizations to provide for and coordinate human resources. This definition reflects the cardinal aspects of human resource management as:

- Action Oriented: To focus on action rather than on record keeping, whether procedures or rules. It emphasizes the solution of employment problems to help achieve organizational objectives.

- Individually Oriented: Human Resource Management considers each employee as an individual and offers services and programmes to meet the individual needs.

- Future Oriented: Human Resources management is concerned with helping an organization achieve its objectives in the future by providing for competent and well-motivated employees.

Japan and Tanzania have chequered history in the effective Human Resource Management in the world in achieving the goals of public sector organization. Japanese Human Resource Management strategy is a package which manifested "life time employment, enterprise unions, seniority based payment system, elaborate welfare provisions, life time training, constant job rotation and collective / consensus decision making" (Imagha 2001). 
Imagha also noted that "an employee is only good as latest targets he achieve one bad performance and the company may threaten termination". On the other hand, Tanzania experimented the use of measurable target and evaluation of workers in the custom service. The result as reported exceeded all expectations (Balogun 1964). In this regards, core civil service and governmental parastatals in Nigeria with economic or quasi economic objectives, such as the Power Holding Company (PHC) NIPOST, Railway and Airways, etc. can equally excel in effective human resource management in consonance with the style adopted by both Japan and Tanzania.

Nigeria can achieve this through designing programme of target / evaluation system in public / private sector organizations that are closely related to reward in the form of promotion and constant workers development package. This approach can reduce the tendency of putting so much premium on material rewards as the only tools of motivation in the public / private sector organizations in Nigeria.

\section{Performance Appraisal or Evaluation}

Any effective human resource management must incorporate workers' performance appraisal system (Decker 1964). It focuses on education and training as a source of capital. It is generally acknowledged that one of the key explanations for the rapid development of Asians Countries in the 1970s and 80s is high investment in human capital (Robert 1991; Psachara and Wordhall 1997). Therefore, human resource training and development decisions and evaluation, which correspond to effective human resource management and appraisal have to be done based on clearly developed capital investment indexes. In his own assessment of the importance of human resources to an organization, (Dike 2010) observed that "human resources play an immense role in the success or failure of any organization, in terms of capability and strength of character of the workers. In Nigeria, most of the problems facing organizations are the reflection of the poor quality of human resources. It is for this reason that the United Nations Development Programme (UNDP) in 2008 ranked Nigeria 157 out of 177 in human development index. Dike further advised that for organizations to grow in Nigeria, "they must educate and train their workforce (that is give them literacy and numeric needed to perform their duties) and must use their talents wisely".

The concept of target setting and performance appraisal originated after the World War $1(1914-1918)$ and pioneered by Walter Dill Scott. The advent of performance appraisal system of technique which this Briton introduced is based on man to man rating system (or merit rating). Between 1920 and 1940, this system gained prominence and was used to evaluate hourly and daily paid workers. It was aggravated through awareness in training and retraining, management and development programmes. By 1950s, the management in both private and public sector organizations adopted performance appraisal system for the evaluation of technical, skilled, professional and managerial personnel as part of training for executive development programmes. This evolutionary trend, led to the change in nomenclature of the term 'merit rating' as a means of performance evaluation. It was not a mere change in nomenclature, but an assessment of change in the scope of the activity as the emphasis (of merit rating) was limited to personnel traits / characteristics (otherwise referred to as subjective system). On the other hand, performance evaluation covers merit, accomplishments, and performance of changing trends in performance evaluation (otherwise referred to as objective system). Therefore, the concept of performance evaluation receives added impetus in Nigeria Public Administration at the instance of both 1988 Civil Service Reform and Ayida Civil Service Reform of (2000).

The rationale or objectives of performance evaluation system in Nigeria public sector organization should be as follows:

1) Feed back for employees regarding how the managers or organizations view their overall performance.

2) Promotion, compensation and transfer or termination decisions.

3) The identification of criteria to allocate organizational rewards as incentive to higher performance.

4) Criteria to evaluate the effectiveness of selection and job placement decision.

5) Ascertaining training and development needs along with criteria to evaluate the success of training and development decision.

6) Establishing effective communication between supervisors and subordinates (reporters and reportees) (Ekpe 1977).

\section{Problems of former Performance Evaluation System in Public Sector Organizations in} Nigeria

The major problems affecting performance appraisal are:

1) Failure of the superiors in conducting performance appraisal and post performance appraisal interviews.

2) Most part of the appraisal is based on subjectivity not objectivity.

3) Less reliability and validity of the performance appraisal technique. 
4) Negative rating affect interpersonal relations and industrial relations systems.

5) Influence of external environmental factors and uncontrollable internal factors.

6) Feedback and post appraisal interview may have a set back on production.

7) Management emphases on punishment rather than development of an employee in performance appraisal.

8) Some ratings particularly about the potential appraisal are purely based on guess work.

9) Relationship between appraisal rates and performance after promotions was not significant.

10) Some superiors completed appraisal reports within a few minutes

11) Absence of inter-rater reliability.

12) The situation was unpleasant in feedback interview

13) Superiors lack the tact of offering the suggestions constructively to subordinates.

14) Supervisors were often confused due to too many objectives of performance appraisal (Anderson 1980).

\section{Comparison of the Former and current Performance Appraisal Systems}

The former performance appraisal system was subjective whereas the current performance appraisal system is objective. In Table 1 the items and issues emphasized in the former and present appraisal systems are outlined for the purpose of comparison.

Table 1 - Comparison of the Former Performance Evaluation System with the Present one

\begin{tabular}{|l|l|l|}
\hline \multicolumn{1}{|c|}{ Item } & Issues of emphasized in the former appraisal system & $\begin{array}{l}\text { Issues of emphasized in the Present appraisal } \\
\text { system }\end{array}$ \\
\hline Terminology & Merit rating & $\begin{array}{l}\text { Employee appraisal } \\
\text { Performance appraisal }\end{array}$ \\
\hline Purpose & $\begin{array}{l}\text { Determining Qualification for Wage increase, transfer, } \\
\text { promotion, lay off }\end{array}$ & Development of the individual improvement \\
\hline Application & For hourly paid / Casual / temporary workers & $\begin{array}{l}\text { For technical, professional and managerial } \\
\text { employees }\end{array}$ \\
\hline Factors rates & Heavy emphasis on personal traits & Results, accomplishments, performance \\
\hline Techniques & $\begin{array}{l}\text { Rating scales with emphasis upon scores. Statistical } \\
\text { manipulation of data for comparison purpose }\end{array}$ & $\begin{array}{l}\text { Management by objectives, mutual goal setting, } \\
\text { crucial incidents, group appraisal, performance } \\
\text { standards, less quantitative }\end{array}$ \\
\hline Post-appraisal & $\begin{array}{l}\text { Supervisor communicates his rating to employees and } \\
\text { tries to sell his evaluation seeks to have employee } \\
\text { conform to his views }\end{array}$ & $\begin{array}{l}\text { Supervisor stimulates employee to analyze himself } \\
\text { and set own objectives in line with job } \\
\text { requirements, superior is helper and counselor }\end{array}$ \\
\hline
\end{tabular}

Source: Authors' Analysis (2013).

\section{Hypothetical Application and Calculation of Annual Performance Evaluation Report (APER) on Public Servants}

The modus operandi and the calculation based on the new APER assessment Form can be demonstrated as hereunder. For instance, the total number of factors in the new APER Form to be scored is 28. Let us assume that an excellent staff in our Department scores all A's in the 28 factors, his/her total score will be $28 \times 6=168$ points.

Major Divisions in the Guideline: The guidelines provide four (4) main divisions under which officers are to be assessed. These divisions are:

a) Job Assessment / General ability

b) Character Traits

c) Work Habits

d) Leadership Performance

The grading system: $6=\mathrm{A} ; 5=\mathrm{B} ; 4=\mathrm{C} ; 3=\mathrm{D} ; 2=\mathrm{E} ; 1=\mathrm{F}$

Table 2 - Analysis of the four (4) main divisions:

\begin{tabular}{|l|l|c|c|c|}
\hline No. & \multicolumn{1}{|c|}{ Main Division } & No. of Factors & Highest Score & Lowest Score \\
\hline A. & Job Assessment / General Ability & 14 & $14 \times 6=84$ & $14 \times 1=14$ \\
\hline B. & Character Traits & 6 & $6 \times 6=36$ & $6 \times 16$ \\
\hline C. & Work Habits & 4 & $4 \times 6=24$ & $4 \times 1=4$ \\
\hline D. & Leadership Ability & 4 & $4 \times 6=24$ & $4 \times 1=4$ \\
\hline & TOTAL & 28 & 168 & 28 \\
\hline
\end{tabular}

Determination of the $\mathbf{5 0 \%}$ Score: Now let us take a look at some specified cases and how to arrive at the required $50 \%$ assessment on the APER Form. 
Assuming Mr. Mfon Eno is assessed as follows:

$\begin{array}{ll}5 & \text { As } \\ 13 & \text { Bs } \\ 7 & \text { Cs } \\ 3 & \text { Ds }\end{array}$

Therefore, his total numerical score is:

$$
\begin{gathered}
(5 \times 6)+(13 \times 5)+(7 \times 4)+(3 \times 3) \\
=\quad 30+65+28+9=132
\end{gathered}
$$

Now, the total numerical score expected of him is $28 \times 6=168$

His actual score by the reporting officer is 132

Therefore, his percentage score over is $50 \% \underline{132} \times \underline{50}$

$$
\begin{array}{lll}
\frac{132}{168} \times \underline{50}, 1 & \frac{11 \times 25}{1} \\
\frac{14}{7} & & \\
\frac{11 \times 25}{7}= & \underline{272} \quad=79.28 \text { Ans. }
\end{array}
$$

Therefore, Mr. Mfon Eno's score on the APER Form for that year is $39.28 \%$ out of $50 \%$.

From the above hypothetical example, one can easily notice that it is simple and straight-forward especially when the computation is accurate. It is absolutely necessary and in fact a MUST for the principal officers and Heads of Department, Reporting Officers, Countersigning Officers, and all Public Officers to master the basic principles of calculating the percentages if they are to be effective and attend to all related complaints with confidence as authority.

In this hypothetical case, let us assume that there are 2 vacancies for Officers on GL. 08 to be promoted to GL 09 and there are 6 Officers on GL 08 whose performances are shown in Table 3. From the Table, it is noticed that an officer who has an edge over his colleagues on Annual Performance Evaluation definitely has

\begin{tabular}{|c|c|c|c|c|c|c|c|}
\hline No. & $\begin{array}{l}\text { Hypothetical } \\
\text { Names of } \\
\text { Officers and } \\
\text { Seniority }\end{array}$ & $\begin{array}{l}\text { APER } \\
\text { Scores } \\
(50 \%)\end{array}$ & $\begin{array}{c}\text { Perfor- } \\
\text { mance at } \\
\text { Interview } \\
(30 \%)\end{array}$ & $\begin{array}{c}\text { Exams passed or } \\
\text { Additional } \\
\text { Qualification or } \\
\text { Seminar Attended } \\
(15 \%)\end{array}$ & $\begin{array}{c}\text { Seniority } \\
(5 \%)\end{array}$ & $\begin{array}{c}\text { Total } \\
\text { Scores } \\
(100 \%)\end{array}$ & Remarks \\
\hline 1. & $\begin{array}{l}\text { Okon Udo Afia } \\
\text { (8 Years) }\end{array}$ & 18.40 & 17 & 15 & 5 & 55.40 & \\
\hline 2. & $\begin{array}{l}\text { Francisca } \\
\text { Bassey ( } 7 \\
\text { Years) }\end{array}$ & 20.50 & 18 & 15 & 5 & 58.50 & \\
\hline 3. & $\begin{array}{l}\text { Mercy } \\
\text { Abraham }\end{array}$ & 14 & 13 & 15 & 5 & 47 & \\
\hline 4. & $\begin{array}{l}\text { Alice Bassey } \\
\text { Effiong ( } 4 \\
\text { Years) }\end{array}$ & 30 & 25 & 15 & 3 & 73 & $\begin{array}{l}2^{\text {nd }} \text { for } \\
\text { promotion }\end{array}$ \\
\hline 5. & $\begin{array}{l}\text { Mfon Eno (3 } \\
\text { Years) }\end{array}$ & 39.28 & 25 & 15 & 2 & 81.28 & \\
\hline 6. & $\begin{array}{l}\text { Peter Ekpo ( } 4 \\
\text { Years) }\end{array}$ & 35 & 20 & 15 & 2 & 72 & $\begin{array}{l}1^{\text {st }} \text { for } \\
\text { promotion }\end{array}$ \\
\hline
\end{tabular}
more chances on the overall total scores. Since $50 \%$ is allotted to the performance alone, it goes back to reinforce the fact that the new APER form places emphasis on performance through attaining the said targets rather than on seniority. Again, for an officer to be considered for promotion, such an officer must work hard and perform effectively.

Table 3: Hypothetical Detail Performance Appraisal results of six officers

Source: Authors' Initiative (2012).

\section{Conclusion}

This paper conceives strategic human resource management as a process of increasing knowledge, skills and capacities of workers and anchored on the new public management precept - which is shopping basket of management focusing on performance standard and outputs having corresponding impact, and effectiveness, if it is supported by effective performance appraisal system to strengthen performance capacities and potentials of workers. It is advocated that there should be a synergy between human resources management 
practice and performance evaluation system to enhance performance capabilities and potentialities of workers. Again, at the organizational level, a holistic and balanced view of Human Resources Development is necessary in order to ensure not only an all-round development of the organizations' human resources, but also to stem the wastes and dwindling of these most valuable assets of the public sector organizations in Nigeria.

\section{Recommendations}

1. It is recommended that the reporting officers or scheduled supervisors of public organizations should be trained specifically on how to compute and calculate the new Annual Performance Evaluation Report (APER) in public sectors organizations. This will certainly ease and facilitate a hitch free and accurate computation of workers' appraisal.

2. As a conscious strategy, the Federal Government should consider the initiation of a national human resource policy which conceives Human Resource Development (HRD) as a package of many interrelated and complimentary activities, such as education, health, nutrition, culture, food, employment, training, retraining and development.

\section{References}

[1]. Anderson, G. (1980). Performance Appraisal: Theory and Practice. USA: Rerton

[2]. Armstrong, M (2005). A Handbook of Human Resources Management Practice, $9^{\text {th }}$ Edition. London: Combram Printers Ltd.

[3]. Balogun, M. (1964). Public Administration in Nigeria: A Development Approach, London: The Macmillan Ltd.

[4]. Decker, T. (1964). The Multidimensional view of Government and Theory of Research Action: A Comparative Evaluation. Journal of Management, 21 (4): 617 - 638.

[5]. Dick, K. (2010). 100 Years of British Rule in Nigeria. Lagos: Noki Publishers.

[6]. Druker, P. (1990). The Practice of Management. London: Heinemann.

[7]. Ekpe, A. (1977). Target and Performance Management Evaluation: An Introductory Reader. Uyo: Frontier Quarterly.

[8]. Imagha, E. (2001). Administrative and Management Theory and Practice. Enugu: Law Publishers.

[9]. Miller, E. and Burack, C. (1981). Strategic Human Resource Management and Assessment of Progress. Human Resource Management Journal, 1 (4): 48 - 52.

[10]. Psachara,P. and Word, H. (1997). Total Renewal from Strategy to Implementation, World at Work. Scottsdate: AZ.

[11]. Subba, R. (2000). Personnel / Human Resource Management. Delhi: Konark Pub. Ltd.

\section{Bibliography}

Dala, J. (1965). Swage Incentives and Production. New York: Elliot.

Roberts, G. (1991). A Dictionary of Polited Analysis. London: Longman.

Tyson, S. (1997). Human Resource Strategy a Process for Managing the Contribution of HRM to Organization Performance. International Journal of Human Resource Management, 8(3): 20-26. 